\title{
Market Orientation and the Performance of Small and Medium-Sized Manufacturing Enterprises in the Accra Metropolis
}

\author{
Francis Boachie-Mensah ${ }^{1} \&$ Kassimu Issau ${ }^{1}$ \\ ${ }^{1}$ School of Business, University of Cape Coast, Cape Coast, Ghana \\ Correspondence: Francis Boachie-Mensah, School of Business, University of Cape Coast, Cape Coast, Ghana, \\ Tel: 233-033-213-7870. E-mail: fbmens2002@yahoo.co.uk
}

\author{
Received: March 2, $2015 \quad$ Accepted: April 2, $2015 \quad$ Online Published: May 31, 2015 \\ doi:10.5539/ijms.v7n3p39 URL: http://dx.doi.org/10.5539/ijms.v7n3p39
}

\begin{abstract}
The importance of small and medium-sized manufacturing enterprises as an engine of economic growth has been widely recognized. However, despite their invaluable contribution in the Ghanaian economy, their performance has not been impressive due to the orientation of their marketing strategies. This study, therefore, sought to investigate the relationship between market orientation and the performance of small and medium-sized manufacturing enterprises in the Accra metropolis of Ghana. Given the purpose and nature of this study where most of the analyses were quantitative in nature, quantitative research approach was deemed the most appropriate and, therefore, adopted. The descriptive and correlational study designs, too, were adopted for this study. Simple random sampling technique, specifically lottery method, was used to select 346 small and medium manufacturing enterprises in the Accra metropolis. Regression analysis was used to test the hypotheses postulated. It was observed from the findings that positive relationship exists between market orientation and small and medium-sized manufacturing enterprises performance. This means that market orientation contribute positively to the well being of small and medium-sized manufacturing enterprises. The study recommends that policy makers as well as National Board for Small Scale Industries should sensitize owners/managers of small and medium-sized manufacturing enterprises about the importance of employing market orientation practices in their business operations.
\end{abstract}

Keywords: market orientation, performance, manufacturing, SMEs

\section{Introduction}

In today's globalised and highly competitive business environment with environmental conditions changing continuously, the success of an organisation shall be possible by obtaining, keeping and maintaining the competitive advantage. In order to obtain and maintain competitive advantage, firms should direct their affairs to be market-oriented and consistently create higher values for their customers (Naktiyok, 2003). Thus, the customer is the main focus for any successful business. Business success depends on a firm's understanding and meeting customers' needs and demands (Boohene \& Agyapong, 2011). Therefore, to compete and survive in the severely competitive marketplace, firms have to pay more attention to the needs and wants of customers.

Organisations world-wide, as a matter of necessity, must endeavour to take the right steps towards achieving their objectives of satisfying the needs and wants of their customers. In view of this, a careful method is often chosen to help organisations to understand their customers, competitors and the various environmental variables, which could determine their success or failure (Kotler \& Armstrong, 2006). Consequently, the field of marketing is, therefore, called into play to help organisations swim through these delicate and sensitive territories. The success of organisations, therefore, hinges on the one that understands the needs, wants and the changing tastes and preferences of customers.

Following the works of Walker (2001) and Webster (1988), until the mid -1950s, the traditional view of marketing held that greater sales volume by organisations was a key to profitability, and, therefore, it was the responsibility of marketing to sell whatever the firm could produce through the use of marketing communications techniques to influence consumer behaviours. As a result, several marketing philosophies, including production orientation, and selling orientation have been adopted by organisations to achieve this objective (Avlontis \& Gounaris, 1999; Diamantopolous \& Hart, 1993). However, most of the approaches were "inside-out" method with little or no focus on the external (customers) environment, hence the adoption of the 
marketing concept (Dobni \& Luffman, 2000; Felton, 1959; Kotler \& Armstrong, 2006; Levitt, 1965). The marketing concept holds that organisations can achieve their objectives in the marketplace through the satisfaction of customer needs.

Since the beginning of the 1990's, the concept of market orientation has attracted immense attention from marketing academics. This is not surprising because it is widely accepted that market orientation is employed to implement the marketing concept, and it indicates the extent to which a company implements the marketing concept (Dobni \& Luffman, 2000; Agarwal, Erramilli, \& Dev, 2003; Lio, Chang, Wu, \& Katrichis, 2011). The marketing concept was adopted to help organisations to replace short term, tactical sales approach to marketing by long term strategic orientation (Webster, 1988) that encouraged businesses to look at fundamental needs of consumers rather than at transient products (McGee \& Spiro, 1988). Market orientation is seen as a central construct in a theory developed to explain firm performance (Kholi \& Jaworski, 1990; Narver \& Slater, 1990). In the same vein, Slater and Narver (2000) posited that market orientation is the aspect of business culture that motivates employees through the organization to place the highest priority on the profitable creation and maintenance of superior customer values.

The importance of small and medium-sized enterprises (SMEs) as an engine of economic growth has been widely recognized (Bruque \& Moyano, 2007; Zeng, Xie, \& Tam, 2010). For instance, Berry, Rodriguez and Sandee (2001) reported that micro and small manufacturing enterprises in Indonesia employ 67 percent of the total working population in the country in manufacturing establishments. Similarly, in Ghana, micro, small and medium-sized enterprises are said to be a characteristic feature of the production landscape and have been noted to provide about 85 percent of manufacturing employment of Ghana (Abor \& Quartey, 2010).

Despite the invaluable contribution of SME in Ghana, they still face challenges. Among these challenges are access to finance (Arthur, 2003), appropriate technology (UNIDO, 2002), access to raw materials (Meads \& Liedholms, 1998), competition (Murphy, 2007) and market access (Meads \& Liedholms, 1998). At the same time, globalisation has stimulated competition, and, in this environment, market orientation and innovation have become a tool for SMEs for improving their performance as well as for surviving in the international competitive market (Maldonado, Dias, \& Varvakis, 2009; Agarwal, Erramilli, \& Dev, 2003; Lio, Chang, Wu, \& Katrichis, 2010).

Though several studies have been conducted on the market orientation construct in the extant literature (see Kohli \& Jaworski, 1990; Narver \& Slater, 1990; Jaworski \& Kohli, 1993; Mahmoud, Kastner, \& Yeboah, 2010), the studies were mostly concentrated in the developed countries and normally conducted on large firms. Furthermore, in the related literature, market orientation and performance relationship studies were also limited to either service sector enterprises or firms which cut across various sectors. Therefore, the objective of this study was to examine the relationship between market orientation and firm performance in the context of manufacturing SMEs in the developing countries. Specifically, the study sought to examine the relationship between customer orientation and performance, competitor orientation and performance, and inter-functional coordination and performance of small and medium-sized manufacturing enterprises in the Accra Metropolis. The following hypothesis was developed to help achieve the objectives of the study: There is a positive relationship between market orientation and its components and the performance of manufacturing SMEs in the Accra metropolis.

\section{Literature Review}

\subsection{Market Orientation}

In the field of marketing, the concept which has attracted the interest of many scholars is market orientation (Marketing Science Institute, 1990). As a result, a great number of studies have been seen in the last decade, which has approached market orientation from a fundamentally dual perspective: either as a cultural aspect or as a constituent part of organisations' culture (Slater \& Narver, 1995) or as a series of specific conducts in accordance with this orientation (Kohli \& Jaworski, 1990).

Narver and Slater (1990) view market orientation as an organisational culture, comprising three behavioural components of equal importance: customer orientation, competitor orientation, and inter-functional coordination. Customer orientation is realised when firms succeed in creating superior value for customers by placing customer satisfaction at the centre of business operations. For this to occur, companies must understand the entire value chain of buyers together with the cost and revenue dynamics of immediate target buyers and those of other markets. In the light of this, Slater and Narver (1994) opined that employees of market-oriented businesses spend considerable time with their clients, and recognize the need to maintain relationships with them as being important for delivering superior customer value. 
The mere focus of firms on customers is not the panacea to the creation of superior value. Firms are, therefore, required to go beyond that and comprehend the nature of competitors, technologies, and products that customers perceive as alternate satisfiers, and to identify and understand the short-term strengths and weaknesses of principal competitors and long-term capabilities and strategies. An understanding of competitors' strengths/strategies can help firms to recognize the types of products to produce and markets to enter/avoid. In view of this, Slater and Narver (1994) argue that all employees within a firm are responsible for generating competitive intelligence.

The final component of market orientation, as indicated by Narver and Slater (1990), is the inter-functional coordination. This component called for the coordination of personnel and other resources of the various functional units throughout the enterprise in other to create value for buyers (Slater \& Narver, 2000). For example, engineering and production staff in manufacturing industries should regularly discuss their capabilities and limitations with those in sales and marketing, so that capabilities can be leveraged and limitations avoided, when promoting products/services (Slater \& Narver, 1994). The effectiveness and efficiency that benefit customers will be creatively realised when all functions within the organisation are geared towards enhancing buyer value.

However, Kohli and Jaworski (1990) offered a different explanation to market orientation, indicating that market orientation involves behavioural activities, including the generation of market intelligence relating to current and future needs of customers, dissemination of intelligence within an organization and responsiveness to it. These authors see market orientation as an organisational process that places emphasis on one or more departments engaging in activities geared toward getting an understanding of customers current and future needs and factors affecting them, sharing the understanding across the departments and various departments engaging in activities designed to meet select needs of customers. Despite the variability in the conceptualizations of market orientation, it typically focuses on three components; 1) customer focus, 2) competitor focus and 3) inter-functional coordination (Celucha, Kasoufb, \& Peruvembac, 2002). Thus, it can be seen that the approaches of Kohli and Jaworski (1990), and Narver and Slater (1990) are complementary, and not mutually exclusive.

\subsection{Firm Performance}

According to Marr and Schiuma (2003), academic research on firm performance came from a multi-disciplinary field of study, covering accounting, economics, human resource management, marketing and operations management. This varying field of study has resulted in a lack of consensus on a universally accepted definition and measurement of firm performance, rendering it a problematic area in business research (González-Benito \& González-Benito, 2005). Generally, firm performance is seen as a measure of how well an organization or an entity attains its objective. Moullin (2003) defines an organization's performance as "how well the organization is managed" and "the value the organization delivers for customers and other stakeholders."

Firm performance may be measured from either objective perspective, using reported data from independent sources, or subjective perspective where perceptual gauges of actual performance are relied upon (Tangen, 2003). A third option, which is a multi-dimensional performance measurement, combines both objective and subjective measures to ensure a more comprehensive measure (Getz \& Carlsen, 2000).

Though objective performance measurement is preferred on the grounds of objectivity, simplicity and appropriateness for homogeneous samples (Wesson \& Neiva De Figueiredo, 2001), sole reliance on it may lead to the neglect of relevant non-financial indicators. Subjective measures, on the other hand, present an alternative devoid of the challenges associated with the use of objective indicators. Criticism has, however, been levelled against subjective measures as being less precise compared to objective measures (Worku, 2011). However, Dess and Robinson (1984), in their study of self-reported responses compared to archival sources of financial results, found little difference between the two sets. They suggested that the use of self-reported firm performance is appropriate for studies for firms for which archival sources of financial data are unavailable.

\subsection{Market Orientation and Firm Performance}

Researchers over the years have examined the relationship between market orientation (MO) and firm performance, and this has revealed inconclusive results. For example, over the previous 17 years, various researchers (Appiah-Adu, 1997) have examined the effects of MO on firm performance, advocating positive (Kumar, Subramanian, \& Yauger, 1998), negative (Voss \& Voss, 2000), and nonsignificant findings (Greenley, 1995). Even though Rodriguez-Cano, Carrillat and Jaramillo (2004) supported a positive relationship between $\mathrm{MO}$ and enterprise performance in their meta-analysis, other reviews (e.g., Langerak, 2003) have culminated in inconclusive results, suggesting that the relationships are not so straight forward (Olavarrieta \& Friedmann, 2008). 
Although some investigators (Harris, 1998) argued that MO dimensions might not be applicable in small business sectors, others (Pelham \& Wilson, 1996) found positive links between MO and performance in small US firms. Slater and Narver (2000) recommended that additional studies with substantive modifications of conceptual and methodological methods to increase confidence in previous findings be undertaken. It is possible that such contradictory results can be attributed to methodological issues such as the utilization of different MO scales and the application of subjective versus objective performance measures (Noble, Sinha, \& Kumar, 2002). For example, Mahmoud (2011) investigated the market orientation-performance link among Ghanaian SMEs, using a survey to collect data on 191 firms. The author used convenience sampling technique to select a sample size of 600 SMEs within the cities of Accra and Tema. Data were obtained from only 191 units of the study. The study also adopted Narver and Slater (1990), and Jaworski and Kohli's (1993) measuring scales to measure market orientation. The results showed that market orientation led to superior performance.

Correspondingly, the study conducted by Boohene, Agyapong and Asomaning (2012) explored the influence of market orientation on financial performance of small businesses. Simple random sampling method was used to select 332 owner/managers of small firms in the Takoradi metropolis. In addition, factor analysis, correlation coefficient and regression analysis were used to examine the data collected. It was found that there was a positive relationship between marketing orientation and its constituents, and financial performance of small businesses. However, a study by Noble, Sinha and Kumar (2002) on mass merchandisers and discount sectors in the retailing industry identified that customer orientation was not a driver of performance, as these firms were focused primarily on selling low margin, high volume products. Firms with higher levels of competitor orientation, national brand focus, and selling orientation exhibited superior performance. This may be as a result of unique characteristics of each of the elements of market orientation. Thus, Dawes (2000) emphasize that each MO component is not necessarily equally and strongly associated with profitability. Thus, the following hypothesis was, therefore, developed to be tested:

$\mathrm{H}_{1}$ : Market orientation and its components are positively related to performance of manufacturing SMEs in the Accra Metropolis.

\subsection{Conceptual Framework for Market Orientation and Firm Performance}

A research on the concept of market orientation is often based on the pioneering works of Narver and Slater (1990), and Kohli and Jaworski (1990). The conceptual framework for this study was, therefore, based on the works of Narver and Slater (1990), as showed in Figure 1. This is because the authors viewed market orientation as an organisational culture, which can be considered as an intangible asset of a firm that enables it to deliver superior value for its customers through better handling of market information (Hunt \& Lambe, 2000). Figure 1, therefore, illustrates the relationship between market orientation and firm performance, where market orientation is seen as independent variable and firm performance as a dependent variable. Market orientation was measured by customer orientation, competitor orientation and inter-functional coordination, whilst sales growth, profit levels, job creation and customer satisfaction were used to measure firm performance. Key issues and lessons from the review informed the conceptual framework of the study.

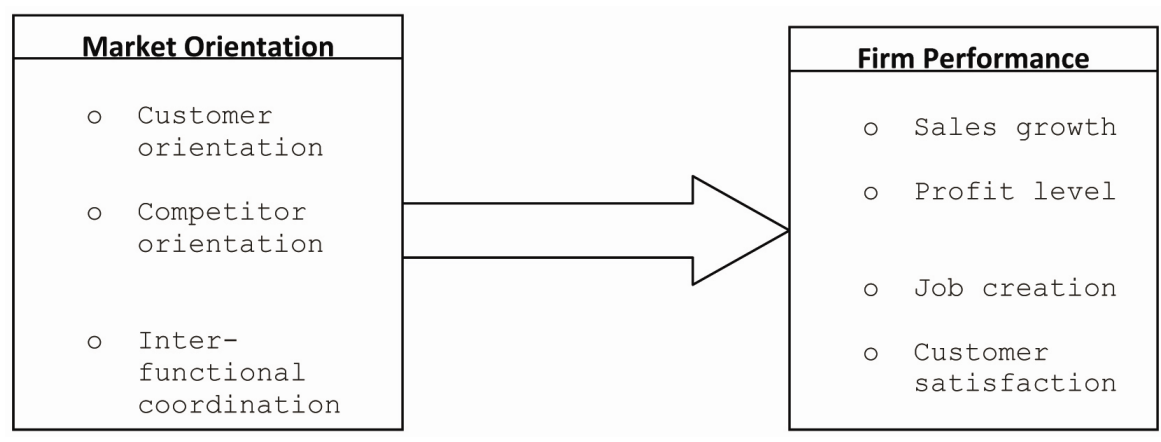

Figure 1. A conceptual framework of market orientation and firm performance

Source: Researchers' construct 2014. 


\section{Methodology}

\subsection{Research Approach and Study Design}

According to Silverman (2011), to obtain the more valid result, selection of the appropriate methodology is highly important. Basically, there are two main approaches to conducting research, namely quantitative and qualitative approaches (Yates, 2004). However, given the purpose and nature of this study where most of the analyses were quantitative in nature, quantitative approach was deemed the most appropriate and, therefore, adopted. The descriptive and correlational study designs were used for this study. The descriptive research design was chosen mainly because it comprises a cross-sectional design in relation to which data are collected predominantly by questionnaire or by structured interview (Bryman \& Bell, 2007, p. 56). The correlational study design was also employed because of its suitability in ascertaining relationship and the strength of relationship between the study variables.

\subsection{Population and Sampling Procedure}

A target population consisted of all the manufacturing SMEs in the Accra metropolis. Out of the total of 3485 manufacturing SMEs found in the sampling frame obtained from National Board for Small Scale Industries, a representative sample of 346 was drawn for the study, using Krejcie and Morgan's (1970) table (see appendix A). Simple random sampling method, specifically lottery method, was adopted in selecting these manufacturing SMEs from the population. This technique was chosen because it provides an opportunity for each of the manufacturing SMEs to have an equal chance of being selected.

\subsection{Measures of Market Orientation and Firm Performance}

Although there are different measures of market orientation (MO), the most predominant ones are the MARKOR (Jaworski \& Kohli, 1993) and MKTOR scales (Narver \& Slater, 1990). However, the general applicability of Narver and Slater's conceptualisation has made it to be widely appraised and hence adopted (Mavondo \& Farrell, 2000). This scale is made up of fourteen questionnaire items, which was subdivided into three parts (Part I-III) to gather information on the market orientation and its dimensions. Part I, II and III sought data on customer orientation (6 questionnaire items), competitor orientation (4 questionnaire items) and inter-functional coordination (4 questionnaire items) respectively. Also, four subjective performance indicators: sales growth, profit level, job creation and customer satisfaction were used to measure performance.

\subsection{Reliability Test}

This study employed alpha co-efficient of 0.5 as its cut-off point. However, the results obtained from Table 1 indicate that all the variables exceeded the Cronbach's alpha co-efficient level of 0.70 , as recommended by Pallant (2007). This, therefore, suggests that all the constructs of the study have good internal consistency reliability and hence can be used in other studies in the Ghanaian context.

Table 1. Computed reliability coefficients for the survey data collected

\begin{tabular}{llll}
\hline Questionnaire Section & No. of Items & Sample Size & Cronbach's Alpha \\
\hline Market orientation & 14 & 281 & .903 \\
Customer orientation & 6 & 281 & .833 \\
Competitor orientation & 4 & 281 & .813 \\
Inter-functional coordination & 4 & 281 & .898 \\
Firm performance & 4 & 281 & .781 \\
\hline
\end{tabular}

Source: Field Work, 2014.

\subsection{Validity Testing}

In this study, content validity, criterion validity, and construct validity were all employed in estimating the validity of an instrument. With regard to content validity, four systematic steps in developing instruments for testing were followed to achieve that purpose. The steps are: (1) carefully defining what is to be measured, (2) Carefully reviewing literature and conducting interviews with the target population, (3) Checking the scale with experts and (4) Pre-testing the scale. All but interviews were employed to ensure content validity of the instrument used in this study. Also, market orientation was regressed on firm performance. The results obtained indicated significant relationships between the variables, suggesting criterion validity of the instrument. 
The final approach, construct validity, was achieved by using convergent and discriminant validity. Principal component analysis, the most commonly used approach for factor extraction (Tabachnick \& Fidell, 2007), was employed in testing for the convergent validity of the scales used in this study, namely market orientation and performance. This technique was employed primarily to summarise large numbers of scale items into smaller numbers of coherent sub-scales by identifying and clumping inter-correlated sets of variables. According to Tabachnick and Fidell's (2007), tests such as sample size (above 150 cases), correlation coefficients ( $\geq .3$ ), Kaiser-Meyer-Olkin (KMO) measure of sampling adequacy and Bartlett test of sphericity must precede factor analysis in order to determine the suitability of the data for factor analysis.

The KMO test is an index which ranges from 0 to 1 with .6 suggested as the minimum value for a good factor analysis (Tabachnick \& Fidell, 2007). Bartlett's test of sphericity provides the statistical probability of a correlation matrix, having significant correlations among, at least, some of the variables. Its significant value should be $(\mathrm{p} \leq .05)$ for factor analysis to be considered appropriate (Pallant, 2007). The results for the KMO and Bartlett's tests respectively were as follows: Market orientation (.880) and (.000) (see appendix B) and performance (.748) and (.000) (see appendix C). Furthermore, majority of the items on all three scales loaded above .3 on the correlation matrices. Convergent validity was thus established among all the scales. Factor analysis was, therefore, deemed appropriate for assessing construct validity of the scales.

Orthogonal rotation was adopted for this study due to its effectiveness in producing discriminant validity by attempting to maximise the factor loading on some variables and minimizing it on others (Hair, Bush, \& Ortinau, 2006). Varimax, the most commonly used orthogonal rotation method, was adopted because of its ability to minimize the number of variables with high loadings as well as its ease of interpretation (Pallant, 2007). The final decision on which factors to retain for further investigation was, however, based on Kaiser's criterion (eigenvalue rule), which represents the total variance explained by a factor. According to the rule, only factors with eigenvalues of 1.0 or more should be retained.

With regard to the results obtained, three components of market orientation loaded above the 1.0 eigenvalue threshold, accounting for 64.58 percent of its variance (see appendix D). Only one component of firm performance loaded above the 1.0 eigenvalue rule, singularly accounting for 61.84 percent of its variance (see appendix E). The results obtained indicated that the components of each of the two variables could be combined into single constructs and analyzed as unilateral variables.

\subsection{Data Collection Procedure and Analysis}

The collection of data for this study started from $1^{\text {st }}$ January 2014 to $28^{\text {th }}$ February, 2014. The study used both primary and secondary sources to achieve the research objective. The self-administered questionnaire was used to collect primary data from key decision makers of the firm, whilst secondary data were obtained from the Internet, journals, text books and other relevant sources. Out of 346 questionnaires distributed, only 321 were retrieved from the respondents. However, 40 out of the retrieved questionnaires were not filled by the respondents, bringing down total usable questionnaire for analysis to 281 . This represents 81.2 percent response rate.

As suggested by Tabachnick and Fidell (2007), and Pallant (2007), the histogram and normal probability plots were relied upon in determining normality of the data. Upon checks, the respective histograms and probability plots (See Appendices F, G) of the data for all the two variables indicated normal distribution. To perform regression analysis, it was required that certain underlying assumptions were met. These assumptions related to sample size, linearity of variables, normality, homoscedasticity of residuals, multicollinearity and outliers. Prior tests were, therefore, carried out to ensure that these assumptions were met. In the case of sample size, Tabachnick and Fidell's (2007) formula for calculating the minimum requirement for use in multiple regression was relied upon. The formula is: $\mathrm{N}>50+8 \mathrm{~m}$ (where ' $\mathrm{N}$ ' $=$ sample size and ' $\mathrm{m}$ ' = number of independent variables). For this study, $\mathrm{N}=281$ and $\mathrm{m}=3$. Since $281>74$, the minimum sample size requirement was duly met. For correlations between independent and dependent variable, Pallant (2007) suggested a minimum of .3 between independent and dependent variables and $<.9$ between independent variables. The values obtained met the stipulated requirements (See appendix $\mathrm{H}$ ).

As suggested by Leech, Barrett and Morgan (2005), and Pallant (2007), linearity, normality and homoscedasticity of residuals, as well as outliers, were checked, using the normal probability plot of the regression standardized residual. For linearity of variables, the reasonable straight diagonal line from bottom left to top right indicated linear relationships between the predictor variable and performance. It also indicated the absence of a deviation from normality. Furthermore, the relative constancy in variances of the residuals about the predicted dependent variable scores indicated homoscedasticity. 


\section{Results and Discussion}

The objective of this study was to determine the relationship that exists between market orientation and performance of manufacturing SMEs in the Accra metropolis as well as test the predictive power of one variable over the other. This study, therefore, used standardised multiple regression and simple regression techniques for data analysis. As recommended by Pallant (2007), correlation values (r) for this study were interpreted according to Cohen's (1988) guidelines, i.e. small $(r=.10-.29)$, medium/moderate $(r=.30-.49)$ and large/strong $(r=.50$ - 1.0). The result of the study, as evidenced in the beta values in Table 2 and depicted in the conceptual framework in Figure 1, suggests that all the three components of market orientation contributed uniquely to explaining variances in firm performance. Customer orientation made the most significant contribution to firm performance $(\beta=.359$; Sig. $=.000)$, while inter-functional coordination contributed the least $(\beta=.292$; Sig. $=.000)$. However, the competitor orientation contributed insignificantly to the variance in firm performance (Sig. > .05), due to overlapping variances with other market orientation components.

Regarding the relationship between market orientation and performance, market orientation shows large positive and significant relationship with the performance of manufacturing SMEs $(\mathrm{R}=.577$; Sig. $=.000$; Table 2). This result further indicates that market orientation explains $33.3 \%$ of the variations in firm performance. The implication is that an increase in market orientation would result in an increase in performance of manufacturing SMEs. Thus, manufacturing SMEs with high market orientation practice would perform well in the market place, thereby ensuring the long-term survivability of the businesses.

In this regard, the hypothesis, which was stated as "Market orientation is positively related to performance of small and medium manufacturing enterprises in the Accra Metropolis", was thus not rejected, because the (p-values: .000) is less than the benchmark alpha of 0.05. This was found to be consistent with the findings of the empirical study conducted by Mahmoud (2011), who found a positive relationship between market orientation and performance of SMEs in Accra and Tema in Ghana. It was also consistent with the findings of Boohene et tal (2012), who established a positive relationship between market orientation and financial performance of small businesses in the Takoradi metropolis.

With respect to the relationship between various components of market orientation and performance, customer orientation shows a positive and significant relationship with the performance of manufacturing SMEs $(\mathrm{R}=.507$; Sig. $=.000$; Table 3). This result further indicates that customer orientation explains $25.7 \%$ of the variations in firm performance. This suggests that if manufacturing SMEs place customer satisfaction at the centre of their operations, their performances would also improve. This can be achieved if firms understand the entire value chain of buyers together with the cost and revenue dynamics of immediate target buyers and those of other markets. The result is, therefore, in line with the assertion of Boohene and Agyapong (2011) that business success depends on the firm's understanding and meeting of customers' needs and demands.

Table 2. Multiple regression analysis of market orientation and performance

\begin{tabular}{llll}
\hline $\mathrm{R}$ & $\mathrm{R}$ Square & Adjusted R Square & Std. Error of the Estimate \\
\hline .577 & .333 & .325 & 2.13062 \\
\hline
\end{tabular}

\begin{tabular}{llllll}
\hline \multicolumn{1}{l}{ Coefficients } & \multicolumn{1}{l}{} & & & \\
\hline & $\mathrm{B}$ & Std. Error & Beta & $\mathrm{T}$ & Sig. \\
CUSTOR & .272 & .047 & .359 & 5.814 & .000 \\
COMPOR & .031 & .070 & .032 & .452 & .652 \\
INTEROR & .243 & .052 & .292 & 4.689 & .000 \\
\hline
\end{tabular}

Dependent Variable: Performance

Source: Field Work, 2014. 
Table 3. Regression analysis of components of market orientation and performance

\begin{tabular}{llllll}
\hline Predictor & $\mathrm{R}$ & $\mathrm{R}$ square & Beta & $\mathrm{t}$ & $\mathrm{sig}$ \\
\hline CUSTOR & 0.507 & 0.257 & 0.507 & 9.817 & 0.000 \\
COMPOR & 0.424 & 0.180 & 0.424 & 7.827 & 0.000 \\
INTEROR & 0.470 & 0.221 & 0.470 & 8.895 & 0.000 \\
\hline
\end{tabular}

Dependent Variable: Performance

Source: Field Work, 2014.

Similarly, competitor orientation also shows a positive and significant relationship with the performance of manufacturing SMEs $(\mathrm{R}=.424$; Sig. $=.000$; Table 3$)$. This result also means that competitor orientation explains $18.0 \%$ of the variations in firm performance. The implication is that an increase in competitor orientation would also results in the correspondent increase in firm performance. This, therefore, suggests that the mere focus of firms on customers is not the panacea to the creation of superior value. Firms are, therefore, required to go beyond that and comprehend the nature of competitors, technologies, and products that customers perceive as alternate satisfiers, and to identify and understand the short-term strengths and weaknesses of principal competitors and long-term capabilities and strategies. An understanding of competitors' strengths/strategies can help firms to recognize the types of products to provide and markets to enter/avoid.

Finally, inter-functional coordination also shows a positive and significant relationship with the performance of manufacturing SMEs $(\mathrm{R}=.470$; Sig. $=.000$; Table 3$)$. This result further indicates that inter-functional coordination explains $22.1 \%$ of the variations in firm performance. The findings, therefore, suggest that if a firm engages more on the coordination of its personnel and other resources of the various units, it would result in higher performance. In the light of this, firms must engage in the coordination of personnel and other resources of the various functional units in order to ensure that all functions within the organization are geared towards enhancing buyer value.

With respect to the findings, the hypothesis, which was stated as "Market orientation components are positively related to performance of small and medium manufacturing enterprises in the Accra Metropolis," was thus supported, because the (p-values: .000) is less than the benchmark alpha of 0.05 . This was found to be consistent with the findings of the empirical study conducted by Boohene et tal (2012), who established a positive relationship between market orientation and its components and financial performance of small businesses in the Takoradi metropolis. It is also in conformity with the findings of Dawes (2000), who asserted that as a result of unique characteristics of each of the elements of MO, each MO component is not necessarily equally and strongly associated with profitability.

\section{Conclusion and Recommendations}

The general objective of this study was to determine the relationship between market orientation and performance of manufacturing SMEs in the Accra metropolis. As a result, a hypothesis was formulated to help achieve this objective. A standardised multiple regression and simple regression techniques were used to test the hypotheses postulated. The major finding of the study is that market orientation has a large positive and significant relationship with firm performance. The strength of this relationship is in line with the suggestions made in the literature. The result also suggests that all the three components of market orientation contribute uniquely to explaining variances in firm performance. Customer orientation made the most significant contribution to firm performance while inter-functional coordination contributed the least. However, the competitor orientation contributed insignificantly to the variance in firm performance due to overlapping variances with other market orientation components.

The following conclusion was reached based on the findings of the study. From the discussions, it was realised that manufacturing SMEs in the Accra metropolis market orientation was found to be positively related to firm performance. The implication is that an increase in market orientation practices by the establishments would result in a corresponding increase in performance. Thus, manufacturing SMEs with high market orientation practice would perform well in the market place, thereby ensuring their long term survivability.

Based on the findings from the study, the following policy recommendations are proposed. Owners/managers of small and medium manufacturing businesses should constantly make an effort to satisfy the needs and wants of customers by delivering superior value for them. This can be achieved by gathering information about wants and needs of customers. Furthermore, owners/managers of small and medium manufacturing businesses should comprehend the nature of competitors, their technologies, and products that customers perceive as alternative 
satisfiers in the marketplace. Knowledge of the competitors would enable the owners/mangers of these businesses to position themselves well in the marketplace, so that they will not be overtaken by surprise by their rivals. Owners/managers of small and medium manufacturing businesses should also share information about customers' needs and competitors' action across the entire business. This will orient everybody in the firm about what is happening in the marketplace, and steps to be taking to take advantage of the situation. In addition, Government should establish funds that can easily be accessed by these establishments so that the businesses can use it to buy the necessary innovative equipments needed to improve upon their performances. Finally, it is recommended that NBSSI, as an institution that deals directly with SMEs, should sensitize them about the importance of employing market orientation practices in their business operations.

In terms of limitations of the study, the confinement of the population to small and medium manufacturing enterprises operating in the Accra metropolis renders the result of the study applicable mainly to these establishments. Secondly, the reliance on key decision makers as the sole respondents raises questions, regarding possible bias, mainly with respect to the assessment of firm performance. Finally, the inability to segregate the small manufacturing enterprises from medium manufacturing enterprises raises the question of general applicability of the result.

Future studies should be carried out across the whole country where there are different types of manufacturing SMEs so as to enhance the generalisability of the study result to all businesses. Furthermore, future studies should focus on soliciting views from both owners and employees of manufacturing SMEs in order to enhance quality of result of the study. Again, a further study should concentrate on a longitudinal design in order to provide more conclusive evidence to the relationship between the variables of interest. Finally, future studies should take into recognition differences between small, medium and large manufacturing enterprises so as to facilitate the comparison of the study result among the businesses.

\section{References}

Abor, J., \& Quartey, P. (2010). Issues in SMEs in Ghana and South Africa International Research. Journal of Finance and Economics, 39, 218-228.

Agarwal, S., Erramilli, M. K., \& Dev, C. S. (2003). Market orientation and performance in service firms: role of innovation. Journal of Services Marketing, 17(1), 68-82. http://dx.doi.org/10.1108/08876040310461282

Appiah-Adu, K. (1997). Customer orientation and performance: A study of SMEs. Management Decision, 36(6), 385-394.

Arthur, P. (2003). The implications of state policy for micro-enterprise development. In Tettey, Puplampu, \& Berman (Eds.), Critical Perspectives on Politics and Socio-Economic Development in Ghana (pp. 153-175). Leiden.

Avlontis, G. J., \& Gounaris, S. P. (1999). Market orientation and its determinants: An empirical analysis. European Journal of Marketing, 33, 1003-1026. http://dx.doi.org/10.1108/03090569910285896

Berry, A., Rodriguez, E., \& Sandee, H. (2001). Small and medium enterprise dynamics in Indonesia. Bulletin of Indonesian Economic Studies, 37(3), 363-384. http://dx.doi.org/10.1080/00074910152669181

Boohene, R., \& Agyapong, G. K. Q. (2011). Analysis of the antecedent of customer loyalty of Telecommunication industry in Ghana: The case of Vodafone Ghana. International Business Research, 4(1), 229-239. http://dx.doi.org/10.5539/ibr.v4n1p229

Boohene, R., Agyapong, D., \& Asomaning, R. A. (2012). Micro level analysis of the market orientation-Small business financial performance nexus. American International Journal of Contemporary Research, 2(1).

Bruque, S., \& Moyano, J. (2007). Organizational determinants of information technology adoption and implementation in SMEs: The case of family and cooperative firms. Technovation, 27(5), 241-253. http://dx.doi.org/10.1016/j.technovation.2006.12.003

Bryman, A., \& Bell, E. (2007). Business Research Methods (2nd ed.). New York: Oxford University Press.

Celuch, K. G., Kasouf, C. J., \& Peruvemba, V. (2002). The effects of perceived market and learning orientation on assessed organizational capabilities. Industrial Marketing Management, 31, 545-554. http://dx.doi.org/10.1016/S0019-8501(02)00187-6

Dawes, J. (2000). Market orientation and company profitability: Further evidence incorporating longitudinal data. Australian Journal of Management, 25(2), 173-199. http://dx.doi.org/10.1177/031289620002500204 
Dess, G. G., \& Robinson, R. B. Jr. (1984). Measuring organizational performance in the absence of objective measures: The case of the privately-held firm and conglomerate business unit. Strategic Management Journal, 5(3), 265-273. http://dx.doi.org/10.1002/smj.4250050306

Diamentopoulous, A., \& Hart, S. (1993). Linking market orientation and company performance in the absence of objective measures. Strategic Management Journal, 1, 93-121.

Dobni, C. B., \& Luffman, G. (2000). Implementing marketing strategy through a market orientation. Journal of Marketing, 16, 895-916. http://dx.doi.org/10.1362/026725700784683690

Felton, A. P. (1959). Making the marketing concept work. Harvard Business Review, 37, 55-65.

Getz, D., \& Carlsen, J. (2000). Characteristics and goals of family owner-operated businesses in the rural tourism and hospitality sectors. Tourism Management, 21(6), 547-560. http://dx.doi.org/10.1016/S0261-5177(00)00004-2

Gonzalez-Benito, J., \& Gonzalez-Benito, O. (2005). Environmental proactivity and business performance: An empirical analysis. Omega, 33(1), 1-15. http://dx.doi.org/10.1016/j.omega.2004.03.002

Greenley, G. E. (1995). Market orientation and company performance. British Journal of Management, 6(1), $1-13$.

Hair, J., Bush, R., \& Ortinau, D. (2006). Marketing research within a changing environment. Revised international edition. New York: McGraw-Hill.

Harris, L. C. (1998). Cultural domination: the key to market-oriented culture? European Journal of Marketing, 32(3/4), 354-73. http://dx.doi.org/10.1108/03090569810204643

Hunt, S., \& Lambe, J. (2000). Marketing's contribution to business strategy: Market orientation, relationship marketing and resource advantage theory. International Journal of Management Review, 2(1), 17-43.

Jaworski, B. J., \& Kohli, A. K. (1993). Market orientation: Antecedents and consequences. Journal of Marketing, 57(3), 53-70. http://dx.doi.org/10.2307/1251854

Kholli, A. K., \& Jaworsky, B. I. (1990). Market orientation: The construct, research propositions and managerial applications. Journal of Marketing, 54, 1-18.

Kotler, P., \& Armstrong, G. (2006). Principles of marketing. New Jersey: Pearson Prentice.

Krejcie, R. V., \& Morgan, D. W. (1970). Determining sample size for research activities. Educational and psychological measurement, 30(3), 607-610.

Kumar, K., Subramanian, R., \& Yauger, C. (1998). Examining the market orientation-performance relationship: A context-specific study. Journal of Management, 24(2), 201-233. http://dx.doi.org/10.1016/S0149-2063(99)80060-9

Langerak, F. (2003). The effect of market orientation on positional advantage and organizational performance. Journal of Strategic Marketing, 11(2), 93-115. http://dx.doi.org/10.1080/0965254032000102957

Leech, N., Barrett, K. C., \& Morgan, G. (2005). SPSS for intermediate statistics: Use and interpretation. Mahwah, NJ: Erlbaum.

Levitt, T. (1965). Exploit the product life cycle. Harvard Business Review, 43, 81-94.

Lio, S., Chang, W., Wu, C., \& Katrichis, J. M. (2011). A survey of market orientation research (1995-2008). Industrial Marketing Management, 40, 301-310.

Mahmoud, A. M., Kastner, A., \& Yeboah, J. (2010). Antecedents, environmental moderators and consequences of market orientation: A study of the pharmaceutical firms in Ghana. Journal of Medical Marketing, 10, 231-244. http://dx.doi.org/10.1057/jmm.2010.12

Mahmoud, M. A. (2011). Market orientation and business performance among SMEs in Ghana. International Business Research, 4(1), 241. http://dx.doi.org/10.5539/ibr.v4n1p241

Maldonado, M. U., Dias, N., \& Varvakis, G. (2009). Managing innovation in small high technology firms: A case study in Brazil. Journal of Technology Management and Innovation, 4(2), 130-142.

Marketing Science Institute. (1990). Research priorities, 1990-1992.

Marr, B., \& Schiuma, G. (2003). Business performance measurement - past, present and future. Management Decision, 41(8), 680-687. http://dx.doi.org/10.1108/00251740310496198 
McGee, L. W., \& Spiro, R. L. (1988). The marketing concept in perspective. Business Horizons, 31(3), 40-45. http://dx.doi.org/10.1016/0007-6813(88)90007-9

Mead, D., \& Liedholm, C. (1998). The dynamics of micro and small enterprises in developing countries. World Development, 26(1), 61-74. http://dx.doi.org/10.1016/S0305-750X(97)10010-9

Moullin, M. (2003). Defining performance measurement. Perspectives on Performance, 2(2), 3.

Murphy, J. (2007). The challenge of upgrading in African Industries: Socio-spatial factors and the urban environment in Mwanza, Tanzania. World Development, 35(10), 1754-1778. http://dx.doi.org/10.1016/j.worlddev.2007.06.003

Naktiyok, A. (2003). Intrepreneurship. Istanbul: Beta Publications.

Narver, J. C., \& Slater, S. F. (1990). The effect of market orientation on business profitability. Journal of Marketing, 54, 20-35.

Noble, C. H., Sinha, R. K., \& Kumar, A. (2002). Market orientation and alternative strategic orientations: A longitudinal assessment of performance implications. Journal of Marketing, 66(4), 25-39. http://dx.doi.org/10.1509/jmkg.66.4.25.18513

Olavarrieta, S., \& Friedmann, R. (2008). Market orientation, knowledge-related resources and firm performance. Journal of Business Research, 61(6), 623-630. http://dx.doi.org/10.1016/j.jbusres.2007.06.037

Pallant, J. (2007). SPSS survival manual: A step by step guide to data analysis using SPSS version 15. New York, NY: McGraw-Hill.

Pelham, A. M., \& Wilson, D. T. (1996). A longitudinal study of the impact of market structure, strategy and market orientation culture on dimensions of small firm performance. Journal of the Academy of Marketing Science, 24(1), 27-43. http://dx.doi.org/10.1177/009207039602400103

Rodriguez Cano, C., Carrillat, F. A., \& Jaramillo, F. (2004). A meta-analysis of the relationship between market orientation and business performance: evidence from five continents. International Journal of Research in Marketing, 2l(2), 179-200. http://dx.doi.org/10.1016/S0167-8116(04)00015-1

Silverman, D. (2011). Interpreting qualitative data. London: Sage Publication.

Slater, S. F., \& Narver, J. C. (1994). Does competitive environment moderate the market orientation-performance relationship? Journal of Marketing, 58(1). http://dx.doi.org/10.2307/1252250

Slater, S. F., \& Narver, J. C. (1995). Market orientation and the learning organization. Journal of Marketing, 63-74. http://dx.doi.org/10.2307/1252120

Slater, S. F., \& Narver, J. C. (2000). The positive effect of a market orientation on business profitability: A balanced replication. Journal of Business Research, 48(1), 69-73.

Tabachnick, B. G., \& Fidell, L. S. (2007). Using multivariate statistics (2nd ed.). Boston: Pearson.

Tangen, S. (2003). An overview of frequently used performance measures. Work Study, 52(7), 347-354. http://dx.doi.org/10.1108/00438020310502651

United Nations Industrial Development Organization (UNIDO). (2002). Rural enterprise development support project. Entrepreneurial skills for group based SMEs. Trainers Manual. Accra.

Voss, G. B., \& Voss, Z. G. (2000). Strategic orientation and firm performance in an artistic environment. Journal of Marketing, 67-83. http://dx.doi.org/10.1509/jmkg.64.1.67.17993

Walker, L. J. (2001). The measurement of a market orientation and its impact on business performance. Journal of Quality Management, 6(2), 139-172.

Webster, F. E. Jr. (1988). The rediscovery of the marketing concept. Business Horizons, 31(3), 29-39. http://dx.doi.org/10.1016/0007-6813(88)90006-7

Wesson, T., \& Neiva De Figueiredo, J. (2001). The importance of focus to market entrants: A study of microbrewery performance. Journal of Business Venturing, 16(4), 377-403.

Worku, T. B. (2011). Horizontal inter-firm cooperation in Ethiopian small and medium enterprises: Evidence from leather shoe manufacturing firms in Addis Ababa. Journal of Small Business and Enterprise Development, 18(4), 806-820.

Yates, S. J. (2004). Doing social science research. London: Sage Publications Ltd. 
Zeng, S. X., Xie, X. M., \& Tam, C. M. (2010). Relationship between cooperation networks and innovation performance of SMEs. Technovation, 30(3), 181-194. http://dx.doi.org/10.1016/j.technovation.2009.08.003

\section{Appendix A}

\section{Table of Sample Selection}

\begin{tabular}{llllll}
\hline$N$ & $S$ & $N$ & $S$ & $N$ & $S$ \\
\hline 10 & 10 & 220 & 140 & 1200 & 291 \\
15 & 14 & 230 & 144 & 1300 & 297 \\
20 & 19 & 240 & 148 & 1400 & 302 \\
25 & 24 & 250 & 152 & 1500 & 306 \\
30 & 28 & 260 & 155 & 1600 & 310 \\
35 & 32 & 270 & 159 & 1700 & 313 \\
40 & 36 & 280 & 162 & 1800 & 317 \\
45 & 40 & 290 & 165 & 1900 & 320 \\
50 & 44 & 300 & 169 & 2000 & 322 \\
55 & 48 & 320 & 175 & 2200 & 327 \\
60 & 52 & 340 & 181 & 2400 & 331 \\
65 & 56 & 360 & 186 & 2600 & 335 \\
70 & 59 & 380 & 191 & 2800 & 338 \\
75 & 63 & 400 & 196 & 3000 & 341 \\
80 & 66 & 420 & 201 & 3500 & 346 \\
85 & 70 & 440 & 205 & 4000 & 351 \\
90 & 73 & 460 & 210 & 4500 & 354 \\
95 & 76 & 480 & 214 & 5000 & 357 \\
100 & 80 & 500 & 217 & 6000 & 361 \\
110 & 86 & 550 & 226 & 7000 & 364 \\
120 & 92 & 600 & 234 & 8000 & 367 \\
130 & 97 & 650 & 242 & 9000 & 368 \\
140 & 103 & 700 & 248 & 10000 & 370 \\
150 & 108 & 750 & 254 & 15000 & 375 \\
160 & 113 & 800 & 260 & 20000 & 377 \\
170 & 118 & 850 & 265 & 30000 & 379 \\
180 & 123 & 900 & 269 & 40000 & 380 \\
190 & 127 & 950 & 274 & 50000 & 381 \\
200 & 132 & 1000 & 278 & 75000 & 382 \\
210 & 136 & 1100 & 285 & 1000000 & 384 \\
\hline
\end{tabular}

Source: Krejcie and Morgan (1970) S = Sample Size N = Population.

\section{Appendix B}

\section{Exploratory Factor Analysis (Market Orientation)}

\begin{tabular}{lll} 
KMO and Bartlett's Test & \\
\hline Kaiser-Meyer-Olkin Measure of Sampling Adequacy. & .880 \\
Bartlett's Test of Sphericity & Approx. Chi-Square & 2033.365 \\
& Df & 91 \\
& Sig. & .000 \\
\hline
\end{tabular}

\section{Appendix C}

Exploratory Factor Analysis (Firm Performance)

KMO and Bartlett's Test

\begin{tabular}{lll}
\hline Kaiser-Meyer-Olkin Measure of Sampling Adequacy. & .748 \\
Bartlett's Test of Sphericity & Approx. Chi-Square & 351.265 \\
& Df & 6 \\
& Sig. & .000 \\
\hline
\end{tabular}




\section{Appendix D}

Total Variance Explained (Market Orientation)

\begin{tabular}{|c|c|c|c|c|c|c|c|}
\hline \multirow[b]{2}{*}{ Component } & \multicolumn{3}{|c|}{ Initial Eigenvalues } & \multicolumn{3}{|c|}{ Extraction Sums of Squared Loadings } & \multirow{2}{*}{$\begin{array}{l}\text { Rotation Sums of Squared } \\
\text { Loadings }{ }^{\mathrm{a}} \\
\text { Total }\end{array}$} \\
\hline & Total & $\%$ of Variance & Cumulative \% & Total & $\%$ of Variance & Cumulative \% & \\
\hline 1 & 6.208 & 44.341 & 44.341 & 6.208 & 44.341 & 44.341 & 4.203 \\
\hline 2 & 1.833 & 13.091 & 57.433 & 1.833 & 13.091 & 57.433 & 4.414 \\
\hline 3 & 1.000 & 7.145 & 64.577 & 1.000 & 7.145 & 64.577 & 4.354 \\
\hline 4 & .866 & 6.186 & 70.763 & & & & \\
\hline 5 & .730 & 5.215 & 75.978 & & & & \\
\hline 6 & .557 & 3.979 & 79.957 & & & & \\
\hline 7 & .514 & 3.675 & 83.632 & & & & \\
\hline 8 & .449 & 3.206 & 86.838 & & & & \\
\hline 9 & .447 & 3.196 & 90.033 & & & & \\
\hline 10 & .363 & 2.591 & 92.624 & & & & \\
\hline 11 & .349 & 2.491 & 95.115 & & & & \\
\hline 12 & .265 & 1.893 & 97.008 & & & & \\
\hline 13 & .222 & 1.586 & 98.594 & & & & \\
\hline 14 & .197 & 1.406 & 100.000 & & & & \\
\hline
\end{tabular}

Extraction Method: Principal Component Analysis.

\section{Appendix E}

Total Variance Explained (Firm performance)

\begin{tabular}{lllllll}
\hline & \multicolumn{3}{l}{ Initial Eigenvalues } \\
Component & Total & \% of Variance & Cumulative \% & Total & \% of Variance & Cumulative \% \\
\hline 1 & 2.473 & 61.836 & 61.836 & 2.473 & 61.836 & 61.836 \\
2 & .727 & 18.181 & 80.017 & & & \\
3 & .452 & 11.293 & 91.310 & & & \\
4 & .348 & 8.690 & 100.000 & & & \\
\hline
\end{tabular}

Extraction Method: Principal Component Analysis.

\section{Appendix F}

\section{Histogram and Probability Plots (Market Orientation)}
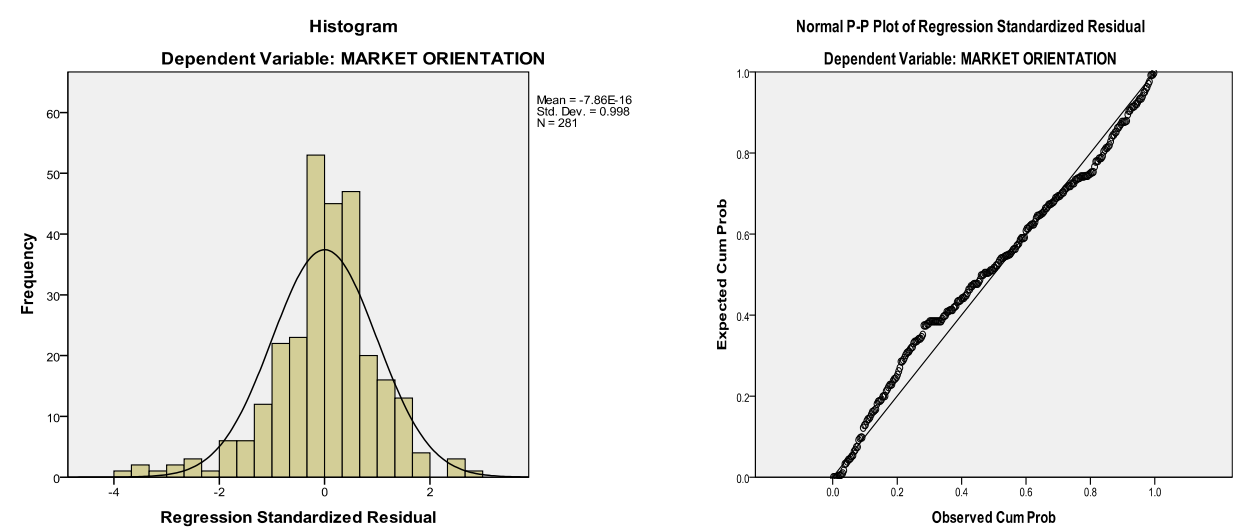


\section{Appendix G}

\section{Histogram and Probability Plots (Firm Performance)}
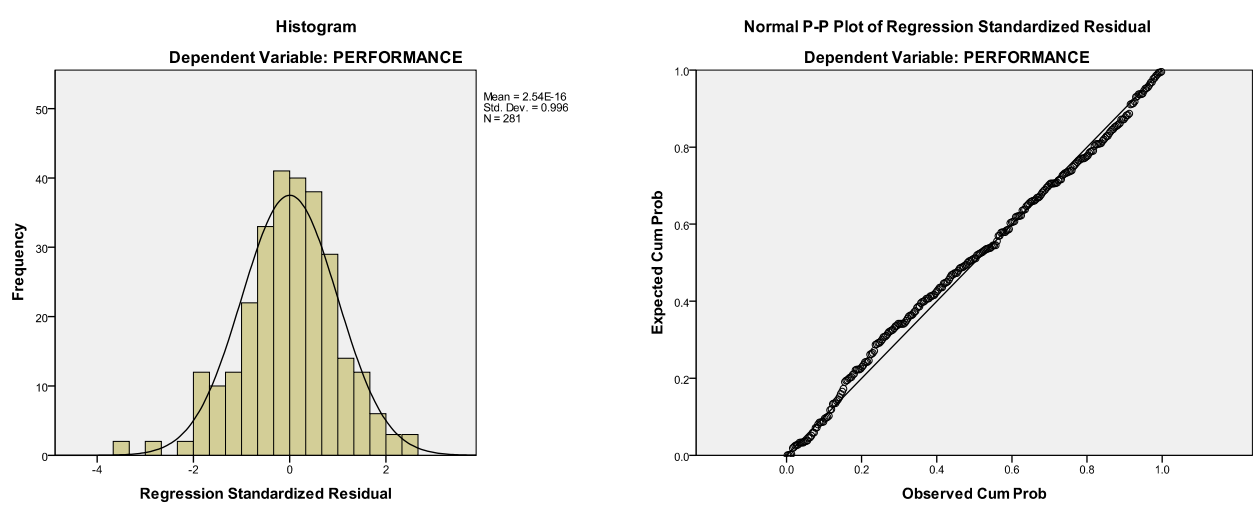

\section{Appendix H}

Correlation matrix for market orientation and its components and performance

\begin{tabular}{|c|c|c|c|c|c|c|}
\hline & MKTOR & CUSTOR & COMPOR & INTEROR & INNOV & PERF \\
\hline MKTOR & 1 & & & & & \\
\hline CUSTOR & $.833^{* *}$ & 1 & & & & \\
\hline COMPOR & $.859^{* *}$ & $.598^{* *}$ & 1 & & & \\
\hline INTREFOR & $.815^{* *}$ & $.441^{* *}$ & $.609^{* *}$ & 1 & & \\
\hline PERF & $.564 * *$ & $.507 * *$ & $.424 * *$ & $.470^{* *}$ & $.456^{* *}$ & 1 \\
\hline
\end{tabular}

**. Correlation is significant at the 0.01 level (2-tailed).

\section{Copyrights}

Copyright for this article is retained by the author(s), with first publication rights granted to the journal.

This is an open-access article distributed under the terms and conditions of the Creative Commons Attribution license (http://creativecommons.org/licenses/by/3.0/). 